\title{
Bioprocess optimization for pectinase production using Aspergillus niger in a submerged cultivation system
}

Hesham A. El Enshasy ${ }^{1,2^{*}}$, Elsayed Ahmed Elsayed ${ }^{3,4^{*}}$ (D), Noorhamizah Suhaimi ${ }^{1}$, Roslinda Abd Malek ${ }^{1}$ and Mona Esawy ${ }^{4}$

\begin{abstract}
Background: Pectinase enzymes present a high priced category of microbial enzymes with many potential applications in various food and oil industries and an estimated market share of $\$ 41.4$ billion by 2020 .

Results: The production medium was first optimized using a statistical optimization approach to increase pectinase production. A maximal enzyme concentration of $76.35 \mathrm{U} / \mathrm{mL}$ (a 2.8-fold increase compared with the initial medium) was produced in a medium composed of (g/L): pectin, 32.22; $\left(\mathrm{NH}_{4}\right)_{2} \mathrm{SO}_{4}, 4.33 ; \mathrm{K}_{2} \mathrm{HPO}_{4}, 1.36 ; \mathrm{MgSO}_{4} .5 \mathrm{H}_{2} \mathrm{O}, 0.05 ; \mathrm{KCl}$, 0.05; and $\mathrm{FeSO}_{4} .5 \mathrm{H}_{2} \mathrm{O}, 0.10$. The cultivations were then carried out in a 16-L stirred tank bioreactor in both batch and fed-batch modes to improve enzyme production, which is an important step for bioprocess industrialization. Controlling the $\mathrm{pH}$ at 5.5 during cultivation yielded a pectinase production of $109.63 \mathrm{U} / \mathrm{mL}$, which was about 10\% higher than the uncontrolled $\mathrm{pH}$ culture. Furthermore, fed-batch cultivation using sucrose as a feeding substrate with a rate of $2 \mathrm{~g} / \mathrm{L} / \mathrm{h}$ increased the enzyme production up to $450 \mathrm{U} / \mathrm{mL}$ after $126 \mathrm{~h}$.

Conclusions: Statistical medium optimization improved volumetric pectinase productivity by about 2.8 folds. Scaling-up the production process in 16-L semi-industrial stirred tank bioreactor under controlled pH further enhanced pectinase production by about 4-folds. Finally, bioreactor fed-batch cultivation using constant carbon source feeding increased maximal volumetric enzyme production by about 16.5-folds from the initial starting conditions.
\end{abstract}

Keywords: Aspergillus Niger, Pectinase, Medium optimization, Bioprocess optimization, Batch culture, Fed-batch culture

\section{Background}

Pectic substances are a class of complex glycosidic polysaccharide compounds with a high molecular weight. They constitute the main components of the middle lamella and primary plant cell wall. Pectinase (EC 3.2.1.15) is an enzyme that hydrolyzes these biopolymers; it breaks down pectin in plant materials. This enzyme attacks and depolymerizes pectin through hydrolysis and esterification reactions. Pectinase splits polygalacturonic acid (pectate polymer) into monoglacturonic acid by opening the glycosidic linkages and breaking ester bonds between carboxyl and methyl

\footnotetext{
*Correspondence: henshasy@ibd.utm.my; eaelsayed@ksu.edu.sa ${ }^{1}$ Institute of Bioproduct Development (IBD), Universiti Teknologi Malaysia (UTM), 81130 UTM, Skudai, Malaysia

${ }^{3}$ Bioproducts Research Chair, Zoology Department, Faculty of Science, King Saud University, 11451 Riyadh, Kingdom of Saudi Arabia

Full list of author information is available at the end of the article
}

groups [1]. This enzyme exists naturally in many plants; however, the industrial production of pectinase is carried out mainly using microbial systems. The food enzyme market was valued at about $\$ 1.4$ billion in 2012, and it is expected to increase up to $\$ 41.4$ billion by 2020, with a Compounded Annual Growth Rate (CAGR) of 6.7\% [2]. In addition, pectinases make up almost $25 \%$ of the global food enzyme market [3]. A large pectinase market is required because of the wide range of applications in the food industry. This enzyme is widely used to degrade plant material in food production industries, as it accelerates fruit juice extraction $[4,5]$. It is also used during juice and wine production, as it breaks down the fruit material, extracts flavors, and increases the clearness of the final product. Interestingly, pectinase reduces production costs in term of a higher yield, less equipment required, and less

(c) The Author(s). 2018 Open Access This article is distributed under the terms of the Creative Commons Attribution 4.0 International License (http://creativecommons.org/licenses/by/4.0/), which permits unrestricted use, distribution, and 
labor, especially during juice concentration [6, 7]. In addition to its extensive use in the juice and wine industries, it is now extended to textile, tea, coffee, and oil extraction and the treatment of pectin rich industrial waste water [8-10].

A large number of bacterial strains, mainly Bacillus spp., yeasts (Yarawia lipolytica and Saccharomyces cerevisiae), and many filamentous fungi, such as Aspergillus niger, A. oryzae, A. awamori, A. sojae, Trichoderma viridiae, T. virens, Penicillium griseoroseum, and Phanerochaete chrysosporium, are potential pectinase producers [3, 11-17]. Of these strains, A. niger has attracted the most attention as a pectinase bioreactory because of its long history in fermentation industries and its status as a Generally Regarded As Safe (GRAS) organism, according to the United States Food and Drug Administration [18]. Despite many reports on the potential uses of solid state fermentation (SSF) as an alternative cultivation system for pectinase production, submerged cultivation is by far the most favorable system for the large-scale production of pectinase, based on its ease in scalability, downstream processes, and optimization through different bio-processing approaches, such as fed-batch and continuous cultivation methods.

Fermentation medium accounts for a large portion of the production cost. Alternative substrates for pectinase production include cheap carbon sources including wheat bran, soybean meal, sugar cane molasses, and agro-industrial wastes, especially from citrus fruits such as sweet orange $(C$. sinensis) and lemon (C. limon) [3, 11]. In China and Southeast Asia, mandarin oranges (C. reticulate) are popular citrus fruits.

In this work, mandarin orange peel was used as a substrate for pectinase production at a semi-industrial scale, using a high yield-producing fungal strain, $A$. niger NRC1ami [19]. First, the medium was optimized for enzyme production using factorial and response surface designs. The Plackett-Burman Experimental Design (PBED) is based on the concept that every factor needs its own base level. Furthermore, it requires $4 n$ experiments to investigate a maximum of $4 n-1$ factors at two levels [20]. The Box-Behnken (BB) response surface design produces second-order polynomial approximations to evaluate responses in certain regions. Both designs use statistical analysis which can improve both of upstream and downstream in many primary and secondary metabolites production processes [21-23]. This approach improves pectinase production quickly, with a significant reduction in medium costs [13]. The optimized medium was prepared in a $16-\mathrm{L}$ stirred tank bioreactor using both batch and fed-batch cultivation strategies for pectinase production.

\section{Methods}

\section{Extraction of pectin from mandarin peel}

The pectin present in mandarin peel was extracted according to the method described by Huong and Luyen [24]. Briefly, $100 \mathrm{~g}$ of clean dried peels were mixed with $1 \mathrm{~L}$ of hot water, and then $500 \mathrm{~mL} 0.72 \% \mathrm{HCl}$ were added. The mixture was incubated at $70{ }^{\circ} \mathrm{C}$ for $9 \mathrm{~h}$, followed by separation of liquid phase. Finally, ethanol was added in an equivalent volume with gentle stirring to precipitate pectin, which was then centrifuged at $3000 \mathrm{rpm}$ and dried overnight at $80{ }^{\circ} \mathrm{C}$. The pectin concentration was determined gravimetrically using Ubbelohde viscometer 3 at $25{ }^{\circ} \mathrm{C}$, where $1 \mathrm{~g}$ of dried pectin was dissolved in $100 \mathrm{~mL} 0.9 \% \mathrm{NaCl}$.

\section{Microorganism and inoculum preparation}

Aspergillus niger NRC1ami was obtained from the National Research Center culture collection (NRC; Cairo, Egypt). This strain was isolated from citrus fruit and exhibits high extracellular pectinase production [19]. Once the culture was prepared in growing culture form, it was sub-cultured on potato dextrose agar (PDA) for 4 days at $30{ }^{\circ} \mathrm{C}$. Spores were harvested in a $50 \%$ glycerol solution for preparation of the master cell bank, and the working cell bank was maintained in a cryogen vial at $-80^{\circ} \mathrm{C}$. Each experiment began by thawing and sub-culturing one vial on PDA. After 4 days of cultivation on an agar plate, $A$. niger spores were collected in saline solution.

Medium for pectinase production and shake flask cultivation The initial pectinase production medium was composed of $(\mathrm{g} / \mathrm{L})$ : pectin, 30.0; $\left(\mathrm{NH}_{4}\right)_{2} \mathrm{SO}_{4}, 3.33 ; \mathrm{K}_{2} \mathrm{HPO}_{4}, 1.0$; $\mathrm{MgSO}_{4} .5 \mathrm{H}_{2} \mathrm{O}, 0.05 ; \mathrm{KCl}, 0.05$; and $\mathrm{FeSO}_{4} .5 \mathrm{H}_{2} \mathrm{O}, 0.10$. The $\mathrm{pH}$ was adjusted to 5.5 before sterilization.

\section{Shake flask and bioreactor cultivation}

Shake flask cultivation was carried out in a $250-\mathrm{mL}$ Erlenmeyer flasks with a $50 \mathrm{~mL}$ working volume, which were inoculated with $1 \times 10^{4}$ spores $/ \mathrm{mL}$. The inoculated flasks were incubated in a temperature-controlled rotary shaker (Innova 4080, New Brunswick Scientific, Edison, NJ, USA) at $150 \mathrm{rpm}$ and $30{ }^{\circ} \mathrm{C}$. The propagated vegetative cells were used as inoculum for either shake-flask or bioreactor cultivations at a ratio of $5 \%$.

A stainless steel, double-jacketed, 16-L stirred tank bioreactor was used (BioEngineering, Wald, Switzerland) with a working volume of $6 \mathrm{~L}$. The stirrer was equipped with two, 6-bladed Rushton turbine impellers $\left(\mathrm{d}_{\mathrm{i}(\text { impeller diameter })}=85 \mathrm{~mm} ; \mathrm{d}_{\mathrm{t}(\text { tank diameter })}=\right.$ $\left.214 \mathrm{~mm}, \mathrm{~d}_{\mathrm{i}} / \mathrm{d}_{\mathrm{t}}=0.397\right)$. Sterilization was carried out at $121{ }^{\circ} \mathrm{C}$ for $30 \mathrm{~min}$. The agitation was adjusted to $200 \mathrm{rpm}$ throughout the cultivation, and aeration was performed using sterile air at a rate of $1 \mathrm{v} / \mathrm{v} / \mathrm{min}$. 
Foam was suppressed during cultivation using Struktul anti-foaming agent (Schill+Seilacher Grupper GmbH, Hamburg, Germany). The $\mathrm{pH}$ and dissolved oxygen were determined during the cultivation using $\mathrm{pH}$ and $\mathrm{DO}$ polarographic electrodes (Ingold, Mittler-Toledo, Greifensee, Switzerland). The $\mathrm{pH}$-controlled culture was adjusted to 5.5 by connecting the $\mathrm{pH}$ controller to an acid/base feeding peristaltic pump containing $5 \mathrm{M} \mathrm{HCl}$ and $5 \mathrm{M}$ $\mathrm{NaOH}$ solutions.

\section{Experimental design}

The Plackett-Burman design was applied to determine the medium components affecting pectinase production. The four key medium components were pectin, $\left(\mathrm{NH}_{4}\right)_{2} \mathrm{SO}_{4}, \mathrm{~K}_{2} \mathrm{HPO}_{4}$ and $\mathrm{MgSO}_{4} .5 \mathrm{H}_{2} \mathrm{O}$; thus, these medium components were selected as variables. The low level $(-1)$ and high levels $(+1)$ of individual nutrients are given in Table 1.

The factors affecting the response of the Plackett-Burmann design were pectin, $\left(\mathrm{NH}_{4}\right)_{2} \mathrm{SO}_{4}$ and $\mathrm{K}_{2} \mathrm{HPO}_{4}$. These three factors were further studied for the optimal range in the Box-Behnken design using Minitab 16 software (Minitab, Ltd., Coventry, UK). The low, center, and high levels are shown in Table 2.

The Box-Behnken design is based on the following second-order polynomial equation:

$$
Y=\beta_{0}+\sum_{i=1}^{k} \beta_{i} x_{i}+\sum_{i=1}^{k} \beta_{i i} x_{i}^{2}+\sum_{i<j} \beta_{i j} x_{i} x_{j}
$$

where $\mathrm{Y}$ is the predicted pectinase activity $(\mathrm{U} / \mathrm{mL}), x_{i}$ and $x_{j}$ are the parameters (pectin, $\left(\mathrm{NH}_{4}\right)_{2} \mathrm{SO}_{4}, \mathrm{~K}_{2} \mathrm{HPO}_{4}$; $\mathrm{g} / \mathrm{L}), \beta_{0}$ is the intercept term, and $\beta_{i}, \beta_{i i}$, and $\beta_{i j}$ are the linear, squared, and interaction coefficients, respectively [25]. The predicted responses obtained from the Box-Behnken design were compared with the actual responses to estimate the accuracy of this methodology.

\section{Analyses \\ Biomass determination}

During shake flask cultivation, samples were withdrawn intermittently for analysis. For the bioreactor cultivation, aliquots $(20 \mathrm{~mL})$ of the culture were taken through a sampling system. Samples were filtered using dry, pre-weighed Whatman filter paper. The supernatant was extracted to determine pectinase activity. The filtered

Table 1 Low and high levels of medium components affecting pectinase production by $A$. niger according to PBED

\begin{tabular}{lll}
\hline Factors & Low level $(-1)$ & High level $(+1)$ \\
\hline Pectin $(\mathrm{g} / \mathrm{L})$ & 10.00 & 30.00 \\
$\left(\mathrm{NH}_{4}\right)_{2} \mathrm{SO}_{4}(\mathrm{~g} / \mathrm{L})$ & 1.30 & 3.30 \\
$\mathrm{~K}_{2} \mathrm{HPO}_{4}(\mathrm{~g} / \mathrm{L})$ & 0.50 & 1.00 \\
$\mathrm{MgSO}_{4} .5 \mathrm{H}_{2} \mathrm{O}(\mathrm{g} / \mathrm{L})$ & 0.05 & 0.50 \\
\hline
\end{tabular}

Table 2 Low, medium and high levels of medium components affecting $A$. niger total enzyme activity and cell biomass in a BB design

\begin{tabular}{lllll}
\hline Factors & Code & Low level $(-1)$ & Middle (0) & High level $(+1)$ \\
\hline Pectin $(\mathrm{g} / \mathrm{L})$ & A & 10.00 & 30.00 & 50.00 \\
$\left(\mathrm{NH}_{4}\right)_{2} \mathrm{SO}_{4}(\mathrm{~g} / \mathrm{L})$ & B & 1.00 & 3.50 & 6.00 \\
$\mathrm{~K}_{2} \mathrm{HPO}_{4}(\mathrm{~g} / \mathrm{L})$ & $\mathrm{C}$ & 0.50 & 1.25 & 2.00 \\
\hline
\end{tabular}

biomass was washed twice using distilled water and dried in an oven at $100{ }^{\circ} \mathrm{C}$ until it reached a constant weight [26].

\section{Enzyme assay}

Pectinase determination was carried out using 1.0\% $(w / v)$ citrus pectin as the substrate; $0.3 \mathrm{~mL}$ of enzyme was added to $0.7 \mathrm{~mL}$ of substrate and mixed for $15 \mathrm{~min}$ at $40{ }^{\circ} \mathrm{C}$. The liberated galacturonic acid concentration was determined using the method described in Esawy et al. [19]. One unit (U) of pectinase was defined as the amount of enzyme producing $1.0 \mu \mathrm{mol}$ of galacturonic acid per min. Enzyme activity was calculated as:

$$
\begin{aligned}
& \text { Activity, } \mathrm{U} / \mathrm{mL} \\
& =\frac{\text { galacturonic acid released, } \mu \mathrm{M} * \text { Dilution factor }}{\text { Incubation time, } \mathrm{min} .}
\end{aligned}
$$

\section{Results}

Plackett-Burman design screening of the main components affecting cell biomass and pectinase production by $A$. niger

Fractional factorial design was applied to find out the most significant medium components affecting pectinase production by $A$. niger. Table 1 shows different investigated medium components and their low $(-1)$ and high $(+1)$ levels. The performed experiments (36 runs, Table 3) revealed that the highest pectinase activity of 87.73-88.85 U/mL was obtained from runs 2, 27 and 29, which were conducted using medium containing (g/L): pectin, 30.0; $\left(\mathrm{NH}_{4}\right)_{2} \mathrm{SO}_{4}, 3.3 ; \mathrm{K}_{2} \mathrm{HPO}_{4}, 0.50$; $\mathrm{MgSO}_{4} .5 \mathrm{H}_{2} \mathrm{O}, 0.50$. Moreover, the coefficients of determination $\left(\mathrm{R}^{2}\right)$ for both cell biomass and pectinase activity were 86.94 and $85.31 \%$, respectively, indicating that this design had a good model fitting.

However, based on the analysis of variance (ANOVA) for pectinase activity (Table 4, Fig. 1), it can be concluded that the first investigated medium components; i.e. pectin, $\left(\mathrm{NH}_{4}\right)_{2} \mathrm{SO}_{4}$ and $\mathrm{K}_{2} \mathrm{HPO}_{4}$, were the most significant factors affecting pectinase production. This can be seen based on the obtained model $F$-value and the lower $p$-value $(p-<0.05)$. Accordingly, magnesium sulphate was excluded from the second step of 
Table 3 PBED with four variables and the actual responses of total enzyme and cell biomass

\begin{tabular}{|c|c|c|c|c|c|c|}
\hline Run & Pectin $(g / L)$ & $\left(\mathrm{NH}_{4}\right)_{2} \mathrm{SO}_{4}(\mathrm{~g} / \mathrm{L})$ & $\mathrm{K}_{2} \mathrm{HPO}_{4}(\mathrm{~g} / \mathrm{L})$ & $\mathrm{MgSO}_{4} .5 \mathrm{H}_{2} \mathrm{O}(\mathrm{g} / \mathrm{L})$ & Response pectinase $(\mathrm{U} / \mathrm{mL})$ & Response CDW (g/L) \\
\hline 1 & 30.00 & 1.30 & 0.50 & 0.05 & 65.52 & 2.20 \\
\hline 2 & 30.00 & 3.30 & 0.50 & 0.50 & 87.73 & 2.08 \\
\hline 3 & 10.00 & 1.30 & 1.00 & 0.50 & 23.00 & 1.70 \\
\hline 4 & 30.00 & 3.30 & 1.00 & 0.05 & 52.32 & 1.80 \\
\hline 5 & 30.00 & 3.30 & 0.50 & 0.50 & 63.22 & 1.88 \\
\hline 6 & 30.00 & 3.30 & 1.00 & 0.05 & 8.94 & 1.75 \\
\hline 7 & 30.00 & 1.30 & 0.50 & 0.05 & 51.88 & 2.33 \\
\hline 8 & 10.00 & 3.30 & 1.00 & 0.50 & 38.87 & 1.75 \\
\hline 9 & 10.00 & 3.30 & 0.50 & 0.05 & 52.99 & 1.00 \\
\hline 10 & 30.00 & 1.30 & 0.50 & 0.05 & 58.70 & 2.45 \\
\hline 11 & 30.00 & 1.30 & 1.00 & 0.05 & 32.92 & 1.89 \\
\hline 12 & 30.00 & 1.30 & 1.00 & 0.05 & 34.90 & 2.25 \\
\hline 13 & 10.00 & 3.30 & 1.00 & 0.05 & 33.79 & 1.00 \\
\hline 14 & 30.00 & 1.30 & 1.00 & 0.50 & 33.95 & 3.10 \\
\hline 15 & 10.00 & 1.30 & 1.00 & 0.50 & 23.00 & 2.00 \\
\hline 16 & 30.00 & 1.30 & 1.00 & 0.50 & 34.74 & 3.05 \\
\hline 17 & 10.00 & 3.30 & 1.00 & 0.05 & 38.47 & 1.18 \\
\hline 18 & 30.00 & 3.30 & 0.50 & 0.50 & 71.71 & 1.65 \\
\hline 19 & 30.00 & 1.30 & 1.00 & 0.50 & 33.16 & 2.65 \\
\hline 20 & 30.00 & 3.30 & 0.50 & 0.50 & 54.74 & 2.10 \\
\hline 21 & 10.00 & 1.30 & 0.50 & 0.50 & 39.66 & 1.65 \\
\hline 22 & 10.00 & 1.30 & 0.50 & 0.50 & 42.92 & 1.75 \\
\hline 23 & 10.00 & 1.30 & 0.50 & 0.05 & 36.25 & 1.40 \\
\hline 24 & 10.00 & 3.30 & 0.50 & 0.05 & 54.89 & 0.90 \\
\hline 25 & 10.00 & 3.30 & 1.00 & 0.50 & 38.71 & 1.65 \\
\hline 26 & 10.00 & 3.30 & 1.00 & 0.50 & 38.79 & 1.70 \\
\hline 27 & 30.00 & 3.30 & 0.50 & 0.50 & 88.85 & 1.85 \\
\hline 28 & 10.00 & 3.30 & 1.00 & 0.05 & 43.15 & 1.25 \\
\hline 29 & 30.00 & 3.30 & 0.50 & 0.50 & 88.29 & 2.30 \\
\hline 30 & 10.00 & 3.30 & 0.50 & 0.05 & 53.94 & 0.95 \\
\hline 31 & 10.00 & 1.30 & 1.00 & 0.50 & 23.00 & 1.85 \\
\hline 32 & 30.00 & 3.30 & 1.00 & 0.05 & 45.69 & 1.70 \\
\hline 33 & 10.00 & 1.30 & 0.50 & 0.50 & 46.17 & 1.70 \\
\hline 34 & 10.00 & 1.30 & 0.50 & 0.05 & 42.04 & 1.30 \\
\hline 35 & 10.00 & 1.30 & 0.50 & 0.05 & 30.46 & 1.35 \\
\hline 36 & 30.00 & 1.30 & 1.00 & 0.05 & 30.94 & 2.07 \\
\hline
\end{tabular}

optimization, since its effect on pectinase production was insignificant $(p-=0.23)$.

Statistical medium optimization using Box-Behnken design The $\mathrm{BB}$ experimental design was further applied to optimize the concentrations of pectin, $\left(\mathrm{NH}_{4}\right)_{2} \mathrm{SO}_{4}$ and $\mathrm{K}_{2} \mathrm{HPO}_{4}$ in the culture medium according to the three levels (low, -1 ; middle, 0 and high +1 ) studied and shown in Table 2. The obtained results (Table 5) clearly showed that highest pectinase activity was obtained upon using the middle levels of all tested three components (Runs 8, 10, 21, 22, 24 and 25), where the maximal pectinase activity obtained ranged from 84.88 to $101.06 \mathrm{U} / \mathrm{mL}$.

The present results show that the applied model exhibited significant $p$-values for the effects of the investigated factors on pectinase production (Table 6). Thus, this model was considered highly significant. From the 
Table 4 Analysis of variance (ANOVA) for the pectinase activity model using BB design for the tested medium components

\begin{tabular}{lllllll}
\hline Source & DF & Sequential SS & Adjusted SS & Adjusted MS & $F$ value & $p$ value \\
\hline Main effects & 4 & 9095.90 & 9095.91 & 2273.98 & 45.01 & 0.00 \\
Pectin & 1 & 2305.20 & 2305.18 & 2305.18 & 45.62 & 56.96 \\
$\left(\mathrm{NH}_{4}\right)_{2} \mathrm{SO}_{4}$ & 1 & 2877.70 & 2877.72 & 3835.82 & 3877.72 & 75.92 \\
$\mathrm{~K}_{2} \mathrm{HPO}_{4}$ & 1 & 3835.80 & 77.1800 & 77.18 & 1.530 & 0.00 \\
$\mathrm{MgSO}_{4} .5 \mathrm{H}_{2} \mathrm{O}$ & 1 & 77.2000 & 1566.27 & 50.52 & 0.00 \\
Residual error & 31 & 1566.30 & 155.210 & 25.87 & 0.460 \\
Lack of fit & 6 & 155.200 & 1411.06 & 56.44 & & 0.83 \\
Pure error & 25 & 1411.10 & & & \\
Corrected total & 35 & $10,662.2$ & & & \\
\hline
\end{tabular}

DF Degree of freedom, SS Sum of squares, MS Mean sum of squares

obtained ANOVA results for the regression model in Table 6, we can deduce the following polynomial:

$$
\begin{aligned}
Y(\text { Pectinase }, U / m L)= & -30.90+4.885 A+12.28 B \\
& +56.8 C-0.09423 A^{2}-1.508 B^{2} \\
& -20.66 C^{2}
\end{aligned}
$$

Response surface plots (Fig. 2a-c) represent correlations between the experimental factors (pectin, $\left(\mathrm{NH}_{4}\right)_{2} \mathrm{SO}_{4}$ and $\left.\mathrm{K}_{2} \mathrm{HPO}_{4}\right)$ and the response of pectinase production. Figure 2a shows the relative effects between $\left(\mathrm{NH}_{4}\right)_{2} \mathrm{SO}_{4}$ concentration $(1.0-6.0 \mathrm{~g} / \mathrm{L})$ and pectin concentration (10-50 g/L) while keeping $\mathrm{K}_{2} \mathrm{HPO}_{4}$ concentration constant at $1.25 \mathrm{~g} / \mathrm{L}$. Pectinase production increased with increasing pectin concentration to reach its maximal production at $32.22 \mathrm{~g} / \mathrm{L}$ of pectin, while
$\left(\mathrm{NH}_{4}\right)_{2} \mathrm{SO}_{4}$ was less effective on pectinase production. Figure $2 \mathrm{~b}$ shows the relative effects between $\mathrm{K}_{2} \mathrm{HPO}_{4}$ concentration $(0.5-2.0 \mathrm{~g} / \mathrm{L})$ and pectin concentration $(10-50 \mathrm{~g} / \mathrm{L})$, while keeping $\left(\mathrm{NH}_{4}\right)_{2} \mathrm{SO}_{4}$ concentration constant at $3.5 \mathrm{~g} / \mathrm{L}$. Results showed that highest pectinase production will be obtained at the most optimum pectin concentration $(32.22 \mathrm{~g} / \mathrm{L})$, while $1.36 \mathrm{~g} / \mathrm{L} \mathrm{K}_{2} \mathrm{HPO}_{4}$ was suitable for producing maximal pectinase production. On the other hand, the combined surface plot for $\left(\mathrm{NH}_{4}\right)_{2} \mathrm{SO}_{4}$ and $\mathrm{K}_{2} \mathrm{HPO}_{4}$ (Fig. 2c), where pectin concentration was fixed at $30 \mathrm{~g} / \mathrm{L}$, shows that increasing both components gradually increased pectinase production up to its maximal, and that further increase resulted in decreased pectinase production. The final optimum concentration for both components were 1.36 and $4.33 \mathrm{~g} / \mathrm{L}$ for $\mathrm{K}_{2} \mathrm{HPO}_{4}$, and $\left(\mathrm{NH}_{4}\right)_{2} \mathrm{SO}_{4}$, respectively. Furthermore, from the model results compared to our experimental runs, it can be seen that the maximal obtained experimental pectinase production $(90 \mathrm{U} / \mathrm{mL})$ was in good

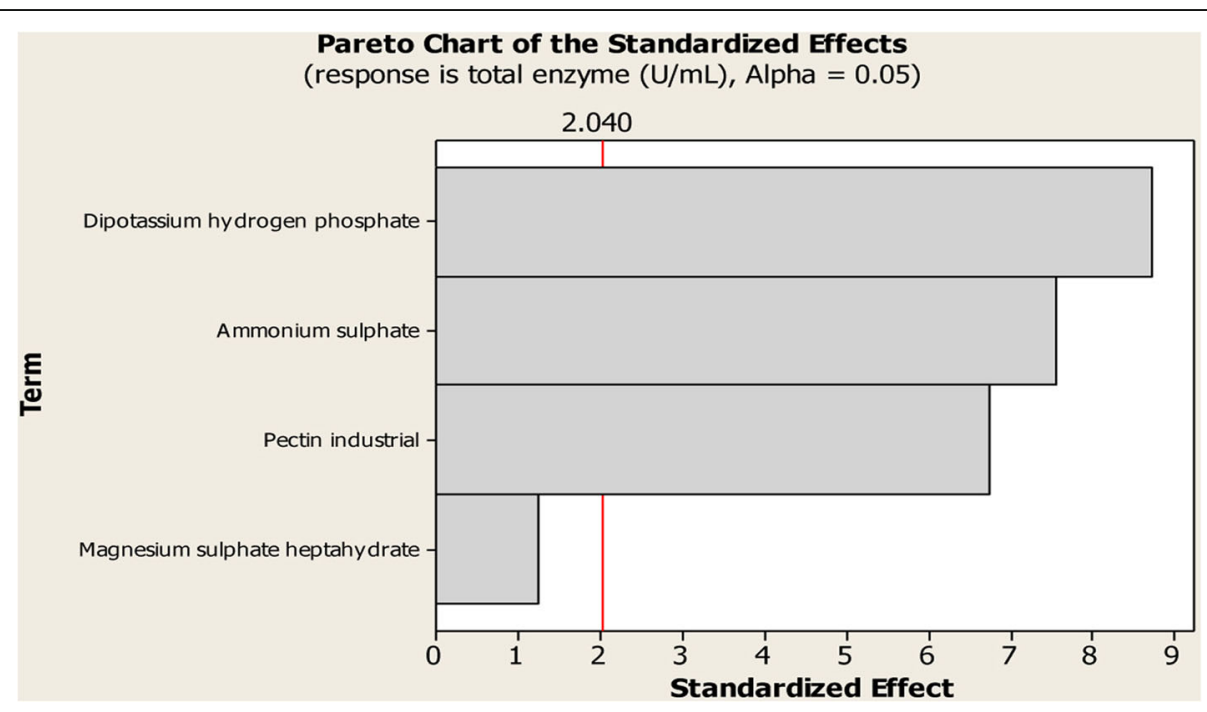

Fig. 1 Pareto chart for the effect of the four factors on total enzyme production 
Table 5 BB design of the experimental setup for response surface design with experimental values of total enzyme and cell biomass

\begin{tabular}{|c|c|c|c|c|c|}
\hline Run & Pectin $(\mathrm{g} / \mathrm{L})$ & $\left(\mathrm{NH}_{4}\right)_{2} \mathrm{SO}_{4}(\mathrm{~g} / \mathrm{L})$ & $\mathrm{K}_{2} \mathrm{HPO}_{4}(\mathrm{~g} / \mathrm{L})$ & Response pectinase $(\mathrm{U} / \mathrm{mL})$ & Response CDW (g/L) \\
\hline 1 & 50.00 & 3.50 & 0.50 & 30.00 & 1.75 \\
\hline 2 & 50.00 & 6.00 & 1.25 & 39.00 & 2.00 \\
\hline 3 & 50.00 & 3.50 & 0.50 & 32.00 & 2.00 \\
\hline 4 & 10.00 & 6.00 & 1.25 & 71.55 & 1.30 \\
\hline 5 & 30.00 & 6.00 & 2.00 & 83.29 & 1.55 \\
\hline 6 & 50.00 & 1.00 & 1.25 & 29.00 & 1.95 \\
\hline 7 & 10.00 & 1.00 & 1.25 & 50.61 & 1.20 \\
\hline 8 & 30.00 & 3.50 & 1.25 & 101.06 & 1.95 \\
\hline 9 & 50.00 & 3.50 & 2.00 & 26.00 & 2.10 \\
\hline 10 & 30.00 & 3.50 & 1.25 & 97.41 & 1.65 \\
\hline 11 & 10.00 & 1.00 & 1.25 & 50.45 & 1.30 \\
\hline 12 & 10.00 & 6.00 & 1.25 & 70.28 & 1.10 \\
\hline 13 & 50.00 & 6.00 & 1.25 & 40.00 & 2.75 \\
\hline 14 & 30.00 & 6.00 & 0.50 & 66.95 & 1.30 \\
\hline 15 & 10.00 & 3.50 & 0.50 & 62.99 & 1.15 \\
\hline 16 & 10.00 & 3.50 & 2.00 & 61.56 & 1.15 \\
\hline 17 & 50.00 & 3.50 & 2.00 & 23.00 & 1.90 \\
\hline 18 & 30.00 & 6.00 & 2.00 & 79.96 & 1.50 \\
\hline 19 & 10.00 & 3.50 & 0.50 & 60.92 & 1.05 \\
\hline 20 & 30.00 & 1.00 & 2.00 & 85.04 & 1.40 \\
\hline 21 & 30.00 & 3.50 & 1.25 & 98.05 & 1.60 \\
\hline 22 & 30.00 & 3.50 & 1.25 & 96.62 & 1.65 \\
\hline 23 & 30.00 & 1.00 & 0.50 & 59.18 & 1.85 \\
\hline 24 & 30.00 & 3.50 & 1.25 & 86.62 & 1.65 \\
\hline 25 & 30.00 & 3.50 & 1.25 & 84.88 & 1.70 \\
\hline 26 & 50.00 & 1.00 & 1.25 & 25.00 & 1.65 \\
\hline 27 & 30.00 & 1.00 & 0.50 & 64.57 & 1.75 \\
\hline 28 & 30.00 & 1.00 & 2.00 & 81.86 & 1.65 \\
\hline 29 & 30.00 & 6.00 & 0.50 & 63.62 & 1.55 \\
\hline 30 & 10.00 & 3.50 & 2.00 & 61.87 & 1.25 \\
\hline
\end{tabular}

Table 6 Estimated regression coefficients for the total enzyme production by $A$. niger using BB design

\begin{tabular}{lllll}
\hline Term & Parameter estimate & SE Coeff. & T value & $p$ value \\
\hline Constant & -30.90 & 2.85 & 33.00 & 0.00 \\
A & 4.89 & 1.75 & -8.81 & 0.00 \\
B & 12.28 & 1.75 & 2.47 & 0.02 \\
C & 56.8 & 1.75 & 2.23 & 0.04 \\
A $^{2}$ & -0.09 & 2.57 & -14.66 & 0.00 \\
B $^{2}$ & -1.51 & 2.57 & -3.67 & 0.00 \\
$C^{2}$ & -20.66 & 2.57 & -4.52 & 0.00 \\
\hline
\end{tabular}

SE Coeff., Standard Error Coefficient agreement with the model predicted production $(92.48 \mathrm{U} / \mathrm{mL})$ with a desirability of 0.915 . It can be generally seen, that the evaluated components are significant for pectinase production. Carbon and nitrogen sources are basic components of fermentation medium, where they are used for cellular growth and metabolic machinery, which is finally reflected on the production of pectinase.

Growth kinetics of $A$. niger cultivated in un-optimized and optimized medium

This part of the work was designed to compare the kinetics of cell growth and pectinase production on both un-optimized and statistically optimized media in shake flasks (Fig. 3). Cells grew exponentially in both cultures for the first $36 \mathrm{~h}$ with a similar growth rate $(0.054 \mathrm{~g} / \mathrm{L} / \mathrm{h})$, 
a Surface plot of total enzyme $(\mathrm{U} / \mathrm{mL})$ vs. ammonium sulphate, industrial pectin

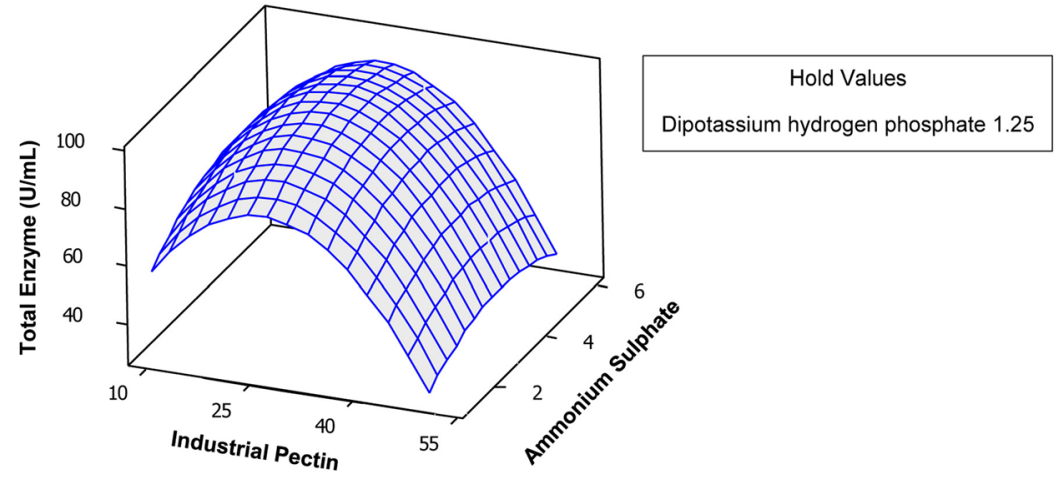

b Surface plot of total enzyme $(\mathrm{U} / \mathrm{mL})$ vs. dipotassium hydrogen phosphate, industrial pectin

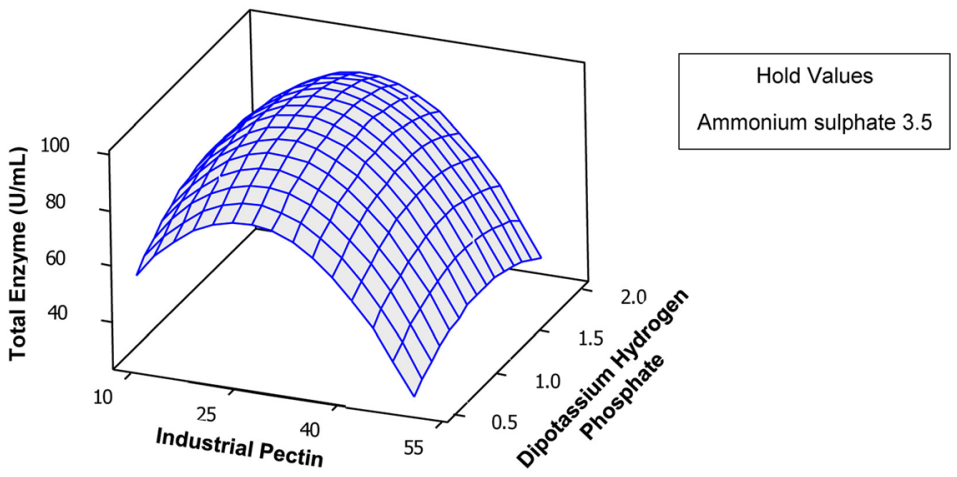

C Surface plot of total enzyme $(\mathrm{U} / \mathrm{mL})$ vs. dipotassium hydrogen phosphate, ammonium sulphate

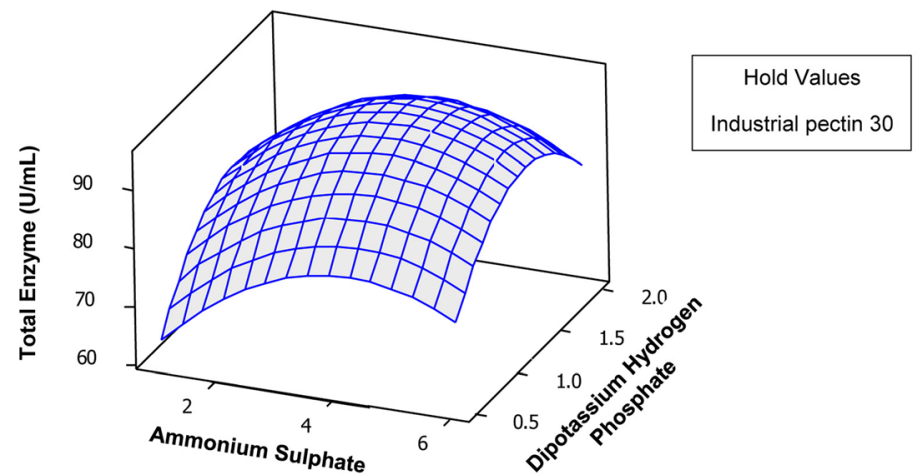

Fig. 2 Contour plots of pecinase production by A. niger showing the interactions between pectin, $\left(\mathrm{NH}_{4}\right)_{2} \mathrm{SO}_{4}$ and $\mathrm{K}_{2} \mathrm{HPO}_{4}$

after which, cell dry weight remained more or less constant till the end of fermentation. Maximal cell growth recorded comparable values by the end of both cultivations (2.26 and $2.29 \mathrm{~g} / \mathrm{L}$ for un-optimized and optimized media, respectively). Moreover, during the early exponential phase $(0-24 \mathrm{~h})$, the $\mathrm{pH}$ dropped from 5.5 to 3.8 and 4.1 in un-optimized and optimized media, respectively, and remained approximately constant for the remaining cultivation time. On the other hand, pectinase production was significantly improved upon using optimized medium, where pectinase was produced at a production rate of about $2.12 \mathrm{U} / \mathrm{mL} / \mathrm{h}$ and recorded a maximal production of $76.35 \mathrm{U} / \mathrm{mL}$ after $36 \mathrm{~h}$. In contrast, in the un-optimized medium, the maximal pectinase achieved was $27.2 \mathrm{U} / \mathrm{mL}$ at $60 \mathrm{~h}$, which was about $35.6 \%$ of the maximal pectinase produced in the optimized medium. Similarly, the production rate in the un-optimized was only $26.9 \%$ $(0.57 \mathrm{U} / \mathrm{mL} / \mathrm{h})$ of the production rate in the optimized medium. Concerning production yield $\left(Y_{\mathrm{P} / \mathrm{X}}\right)$ results showed that the maximal yield obtained in optimized 


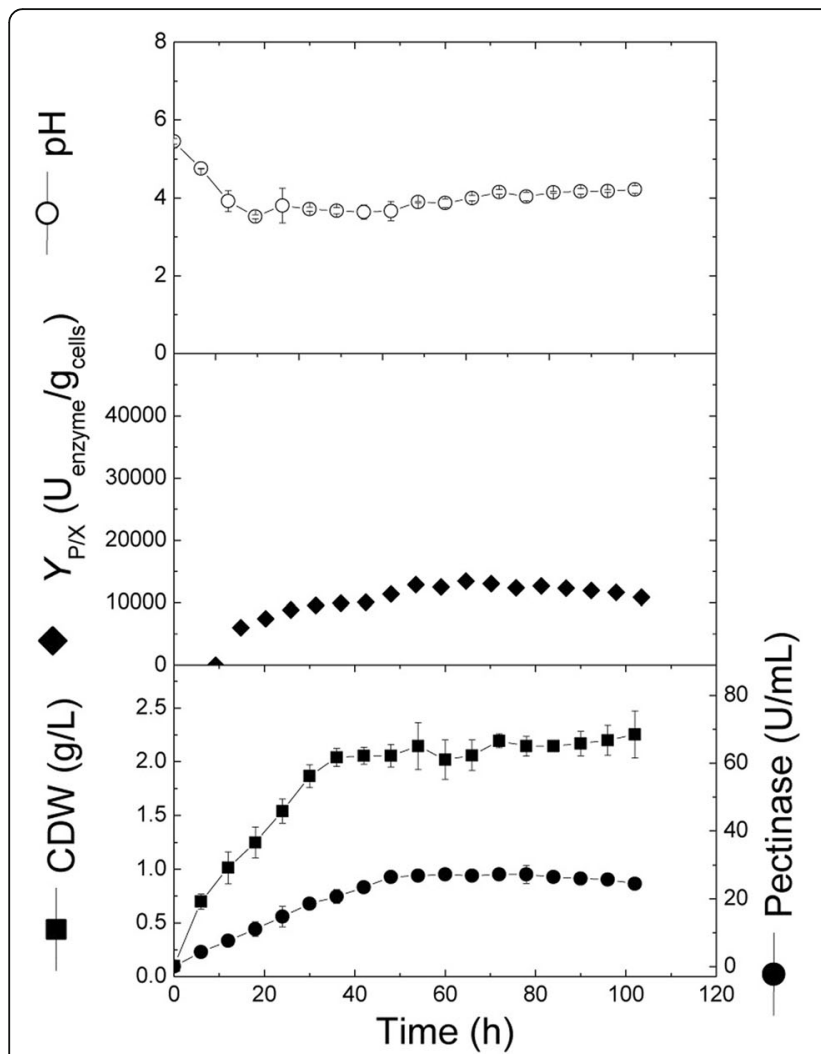

Un-optimized

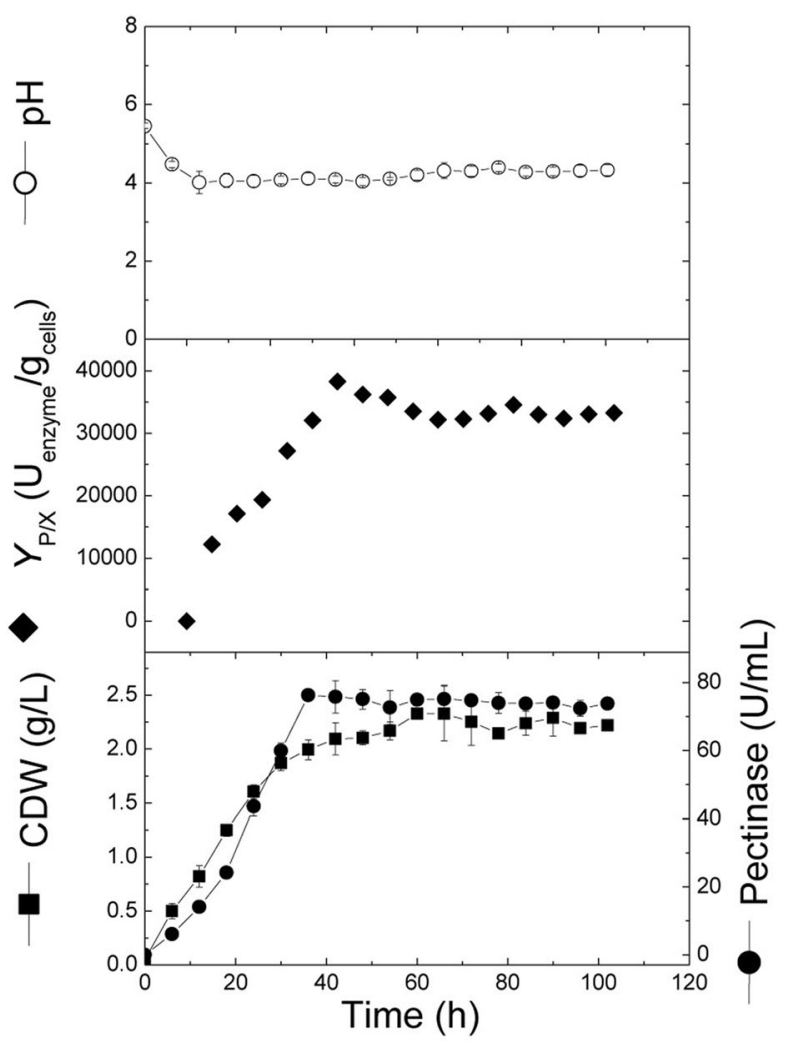

Optimized

Fig. 3 Cell growth, pectinase production, yield coefficient, and pH changes in the shake flask cultures using un-optimized and optimized media

medium (38,270.7 U/g cells) was almost 3 -folds of the maximal yield obtained in un-optimized medium $(12,895.4 \mathrm{U} / \mathrm{g}$ cells).

\section{Batch cultivation in the bioreactor under controlled and uncontrolled $\mathrm{pH}$}

The optimized production conditions were transferred from shake-flask level to bioreactor level to gain insights about process performance in semi-industrial scale bioreactor. Cultivations were run in a $16-\mathrm{L}$ stirred tank bioreactor at an aeration rate of $1 \mathrm{v} / \mathrm{v} / \mathrm{min}$, under uncontrolled $\mathrm{pH}$. This cultivation was compared with cultivation conducted at controlled $\mathrm{pH}$ conditions at 5.5 by the continuous addition of $\mathrm{H}_{2} \mathrm{SO}_{4} / \mathrm{NaOH}$ using a computerized $\mathrm{pH}$ control system (Fig. 4). Results showed that the $\mathrm{pH}$ in the uncontrolled cultivation dropped from 5.5 to about 3.6 after $18 \mathrm{~h}$, and remained more or less constant until the end of the cultivation. It can also be noticed that cells grew exponentially without a lag phase, in both cultivations. Maximal cell growth reached 2.38 and $3.28 \mathrm{~g} / \mathrm{L}$ for uncontrolled and controlled $\mathrm{pH}$, respectively. Additionally, the average cell growth rates were similar $(0.02$ and $0.028 \mathrm{~g} / \mathrm{L} / \mathrm{h}$, for uncontrolled and controlled cultivations, respectively). Concerning pectinase production, results showed that the enzyme was exponentially produced until $84 \mathrm{~h}$ with production rates of 0.94 and $0.86 \mathrm{U} / \mathrm{mL} / \mathrm{h}$ in $\mathrm{pH}$-uncontrolled and -controlled cultivations, respectively. The maximal pectinase produced in $\mathrm{pH}$-controlled cultivation $(109.63 \mathrm{U} / \mathrm{mL})$ was higher by about $10 \%$ from the maximal pectinase produced in $\mathrm{pH}$-uncontrolled cultivation $(99.55 \mathrm{U} / \mathrm{mL})$. This increase in enzyme production can be attributed to the increase in cell biomass rather than the increase in cell productivity, since the maximal recorded production yields $\left(Y_{\mathrm{P} / \mathrm{X}}\right)$ were comparable in both cultivations $(46,282.7$ and 43,760.3 U/g cell for controlled and uncontrolled $\mathrm{pH}$ cultures, respectively). Additionally, both produced maximal pectinase concentrations were higher by about 30.4 (uncontrolled pH) and 43.6\% (controlled $\mathrm{pH})$ than the maximal pectinase produced in optimized shake flask cultivation $(76.35 \mathrm{U} / \mathrm{mL})$.

Fed-batch cultivation in the bioreactor with constant sucrose feeding

Based on the previous data obtained from batch cultivations, fed-batch cultivation was conducted 

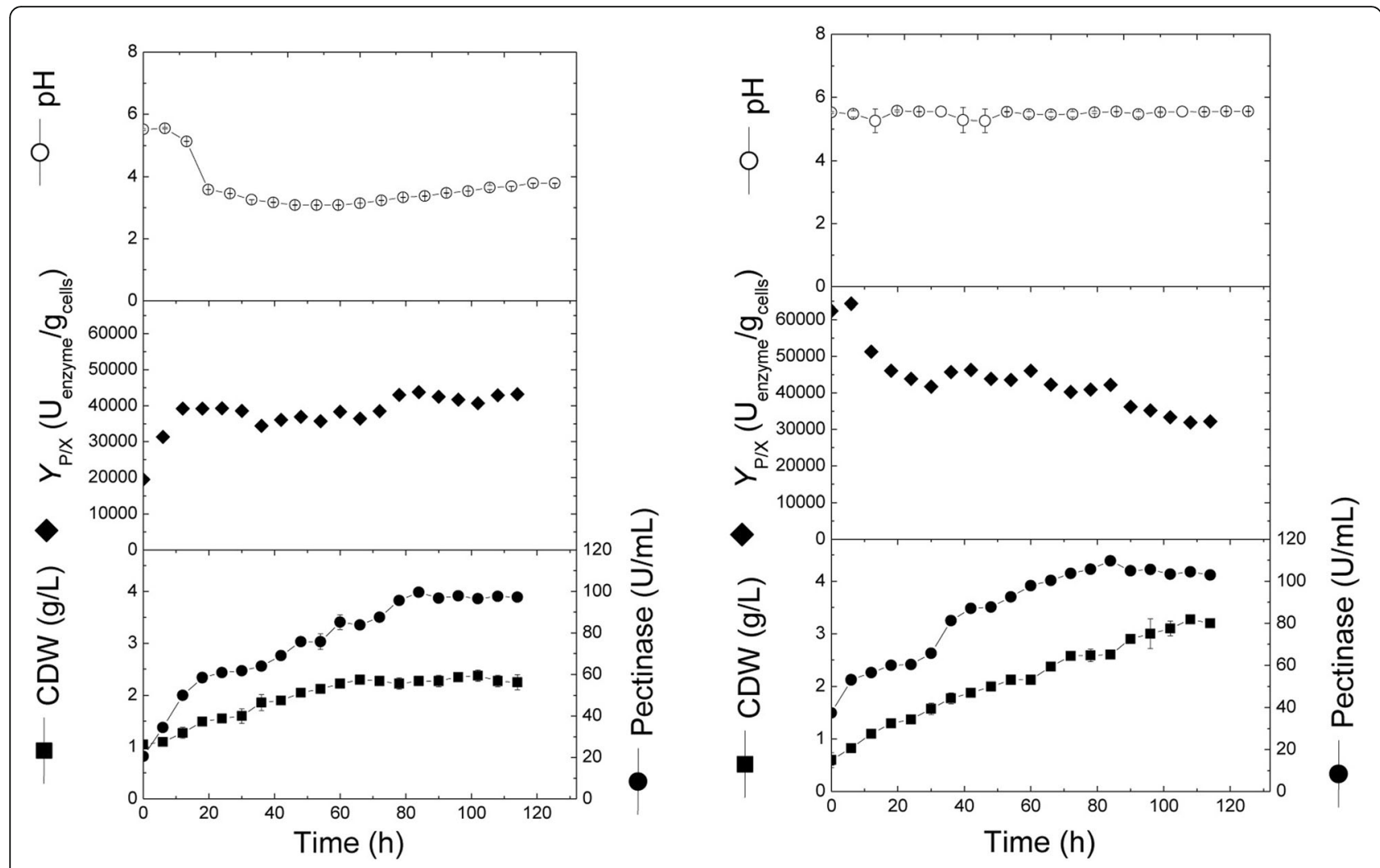

Uncontrolled $\mathrm{pH}$

Controlled $\mathrm{pH}$

Fig. 4 Cell growth, volumetric and specific pectinase production, and change in pH during batch cultivation of A. niger in a 16-L bioreactor under uncontrolled and controlled $\mathrm{pH}$ conditions

under controlled $\mathrm{pH}$ conditions in 16-L stirred tank bioreactor (Fig. 5). The cultivation was started as a normal batch mode for the first $60 \mathrm{~h}$, where the cell growth and pectinase production kinetics were similar to the previous experiments, reaching maximal cell growth and pectinase production of $2.8 \mathrm{~g} / \mathrm{L}$ and $120 \mathrm{U} / \mathrm{mL}$, respectively. At $60 \mathrm{~h}$, and before entering the stationary growth phase, sucrose was added at a constant feeding rate of $2.0 \mathrm{~g} / \mathrm{L} / \mathrm{h}$. Accordingly, cells continued to grow exponentially with the same growth rate $(0.028 \mathrm{~g} / \mathrm{L} / \mathrm{h})$ and reached a maximal of $6.58 \mathrm{~g} / \mathrm{L}$ after $120 \mathrm{~h}$. Concomitantly, the volumetric pectinase production increased with an average production rate of $7.33 \mathrm{U} / \mathrm{mL} / \mathrm{h}$ and reached a maximal of $450 \mathrm{U} / \mathrm{mL}$ at $108 \mathrm{~h}$ (about 4-folds higher than the corresponding batch culture). Afterwards, pectinase production remained approximately constant for the rest of cultivation. The highest production yield coefficient $\left(Y_{\mathrm{P} / \mathrm{X}}\right)$ obtained in the fed-batch cultivation recorded $75,762 \mathrm{U} / \mathrm{g}$ cells, which was almost $63.7 \%$ higher than the highest production yield obtained in $\mathrm{pH}$-controlled batch cultivation (46,282.7 U/g cells).
Finally, Table 7 summarizes different steps applied for the development of the production bioprocess for pectinase enzyme. There were significant increases in both volumetric and specific enzyme production through medium optimization, bioreactor cultivation, and switching to fed-batch mode. The statistical media optimization enhanced the pectinase activity up to $76.35 \mathrm{U} / \mathrm{mL}$, compared with only $26.85 \mathrm{U} / \mathrm{mL}$ in the un-optimized medium in shake flasks. Moreover, cells cultivated in the bioreactor under controlled $\mathrm{pH}$ conditions yielded the highest volumetric pectinase production of $109.63 \mathrm{U} / \mathrm{mL}$. Pectinase production was maximized using sucrose feeding. The highest enzyme production was $450 \mathrm{U} / \mathrm{mL}$ after $108 \mathrm{~h}$, which represented about 16-folds increase in volumetric production, compared with the initial un-optimized culture medium and conditions.

\section{Discussion}

Pectinase enzymes constitute a major sector in the enzyme food market $[3,5,7]$. Accordingly, efforts have been carried out to seek novel compositions of production 


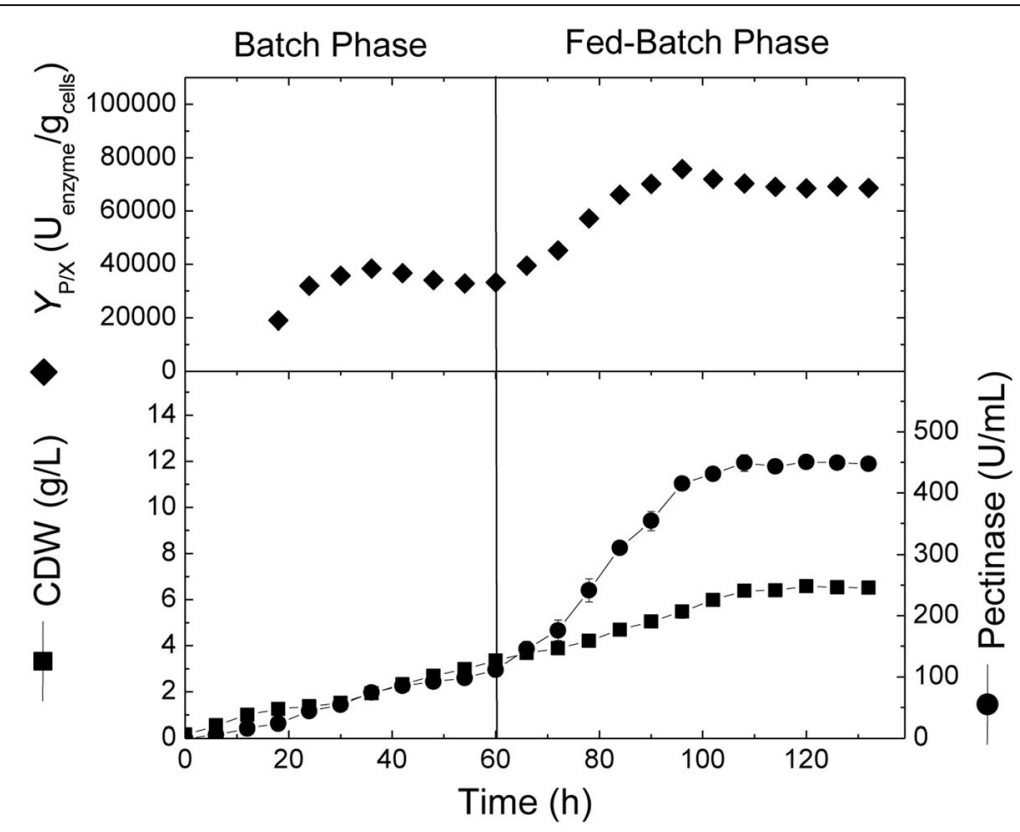

Fig. 5 Cell growth, volumetric and specific pectinase production, and change in pH during fed-batch cultivation of A. niger in a 16-L bioreactor

medium components as well as developed methods for semi-industrial production. In our present study, we investigated the fractional factorial design approach for initial optimization of medium components. Our results showed that pectin, $\left(\mathrm{NH}_{4}\right)_{2} \mathrm{SO}_{4}$ and $\mathrm{K}_{2} \mathrm{HPO}_{4}$, were the most significant factors affecting pectinase production. Furthermore, determination coefficients $\left(R^{2}\right)$ for cell biomass and pectinase activity were 86.94 and $85.31 \%$, respectively, representing a good model fitting. These results are in good agreement with those previously reported for statistical medium optimization for pectinase production using either fungal or bacterial microorganisms $[5,27,28]$. Authors concluded that $\mathrm{MgSO}_{4}$ is not significantly affecting pectinase production during their statistical optimization experiments. Although $\mathrm{Mg}^{+2}$ acts generally as an inducer or co-factor for enzyme production, however, few reports have suggested that magnesium sulphate can inhibit glucose 6-phosphate dehydrogenase,
G6PD [29, 30]. G6PD is a key enzyme in the fungal pentose phosphate pathway responsible for the production of NADPH and is directly correlated with biomass and hence enzyme production [31,32].

Secondly, Box-Behnken design was performed in order to further optimize the concentrations of the obtained most significant components; pectin, $\left(\mathrm{NH}_{4}\right)_{2} \mathrm{SO}_{4}$ and $\mathrm{K}_{2} \mathrm{HPO}_{4}$. We found that highest pectinase activity was obtained using the middle levels of all tested three components (Table 5: Runs 8, 10, 21, 22, 24 and 25). Our obtained results can be correlated with those obtained by Ghazala et al. [10] who investigated statistical optimization of medium components for the production of pectinase by Bacillus mojavensis using carrot peel powder as a substrate. Their results also found that the middle level of carrot peel powder (0) was the best level for the production, and that pectinase levels decreased significantly when the higher levels were used $(+1)$. The

Table 7 Kinetic Parameters for A. niger cell growth and pectinase production under different cultivation conditions

\begin{tabular}{|c|c|c|c|c|c|}
\hline \multirow[t]{3}{*}{ Parameters } & \multicolumn{2}{|l|}{ Shake Flask } & \multicolumn{3}{|l|}{ Bioreactor } \\
\hline & \multirow{2}{*}{$\begin{array}{l}\text { Un-optimized } \\
\text { Medium }\end{array}$} & \multirow{2}{*}{$\begin{array}{l}\text { Optimized } \\
\text { Medium }\end{array}$} & \multicolumn{2}{|l|}{ Batch } & \multirow[t]{2}{*}{ Fed-batch } \\
\hline & & & Controlled pH & Uncontrolled pH & \\
\hline$X_{\max }(g / L)$ & 2.26 & 2.29 & 3.28 & 2.38 & 6.58 \\
\hline$\mu\left(h^{-1}\right)$ & 0.01 & 0.01 & 0.01 & 0.01 & n.d. \\
\hline $\mathrm{Pec}_{\max }(\mathrm{U} / \mathrm{mL})$ & $27.2(60$ h) & 76.35 (36 h) & 109.63 (84 h) & 99.55 (84 h) & 450 (108 h) \\
\hline $\mathrm{Q}_{\mathrm{Pec}}(\mathrm{U} / \mathrm{mL} / \mathrm{h})$ & 0.57 & 2.12 & 0.86 & 0.94 & 7.33 \\
\hline$Y_{\text {Pec/X }}(U / g)$ & $12,517(48$ h) & $38,270(36$ h) & $46,283(42$ h) & 43,760 (84 h) & $75,762(94 h)$ \\
\hline
\end{tabular}

n.d. Not determined

$X_{\max }$ : maximal cell dry weight, $\mu$ : specific growth rate; $P \mathrm{Pe}_{\max }$ : maximal pectinase production; Qpec: pectinase production rate; $Y_{\mathrm{Pec} / X}$ : yield of pectinase on biomass 
model for pectinase activity was used to calculate the coefficient of determination $\left(\mathrm{R}^{2}\right)$, which can be defined as the ratio of the expected deviation to the overall deviation. Our results showed that $\mathrm{R}^{2}$ has a value of $93.69 \%$ for pectinase response, which indicates a good fitting of the model and that the model can explain $93.69 \%$ of the deviation from the expected values, and that only $6.31 \%$ of the deviation cannot be explained by the proposed model. Moreover, as the value of $\mathrm{R}^{2}$ comes closer to 1.0, this means that the model correlates well [5]. Furthermore, the obtained results are in good accordance with those reported by Tari et al. [13], where they stated that the $p$-value reflects the relationship between the variables/factors and the response variable, i.e. $p$-value lower than 0.05 indicates that the applied model is significant.

The comparison of cultivation performance between un-optimized and optimized medium composition in terms of cell growth and pectinase production was carried out. Although, results showed similarities corresponding to cellular growth patterns in both conditions, however, pectinase production significantly increased upon medium optimization in terms of production rate and production yields. The obtained results are generally in good agreement with those reported in the literature for pectinase production. Pectinase literature shows that the maximal enzyme production is usually achieved at early growth stages $(24-30 \mathrm{~h}$ ), which are in good agreement with our results [33]. Statistical approaches have been applied for the optimization of medium components affecting pectinase production. Tari et al. produced pectinase efficiently and cost effectively using statistical optimization methods [13]. Furthermore, Kuvvet et al. applied statistical designing approaches to optimized cultivation medium containing apple pomace for the production of pectinase using Bacillus spp. [17]. They were able to obtain a 2-fold increase in pectinase production using Box-Behnken response surface methodology.

A. niger is an aerobic microorganism and thus needs a continuous supply of oxygen during cultivation for growth and efficient metabolite production [34]. Therefore, cultivations were run in a $16-\mathrm{L}$ stirred tank semi-industrial bioreactor under both uncontrolled and controlled $\mathrm{pH}$ conditions. Results showed that bioreactor cultivations significantly improved cellular growth as well as pectinase production parameters in comparison to shake flask cultivations. Additionally, $\mathrm{pH}$-controlled conditions favored maximal cell growth and pectinase production over $\mathrm{pH}$-uncontrolled conditions. The aforementioned results clearly demonstrate the superiority of bioreactor cultivations over shake flask ones. This can be explained due to the improved oxygen availability and agitation conditions present in bioreactor cultivations [22, 35]. Moreover, the production of industrially important enzymes, i.e. pectinase, amylase and invertase, has been greatly improved upon scaling up the cultivation vessels from shake flask level to bioreactor level [32, 36]. Furthermore, the obtained results showed that the $\mathrm{pH}$ control led to about 10 and $27 \%$ increase in pectinase production and cell growth, respectively. This can be referred to the fact that controlling the $\mathrm{pH}$ of the cultivation provides the growing cells with much more stable cultivation environment which is reflected in the increased cell growth and production. The stability of the cultivation environment was found to be correlated with the intrinsic pathways for nutrient assimilation, cell growth and enzyme productivity [37]. Additionally, the effect of $\mathrm{pH}$ change on enzymes activity has been correlated with enzyme denaturation and destabilization of conformational structures [31].

On the other hand, both bioreactor cultivations showed lower rates of growth and pectinase production than in the case of shake flask cultivations. This decrease can be attributed to the nature of growing fungal hyphae, which under bioreactor conditions tend to have condensed morphology and thus affecting the viscosity of the fermentation broth. Consequently, the cultivation will suffer from decreased oxygen transfer between the condensed hyphae and the viscous broth leading to decreased growth and production rates [38, 39]. Moreover, Friedrich et al. reported that oxygen transfer and viscosity problems in bioreactors greatly affected pectinase production by $A$. niger and they were able to overcome such problems by increasing the agitation from 300 to $600 \mathrm{rpm}$ and the aeration rate from 0.5 to $1.2 \mathrm{v} / \mathrm{v} / \mathrm{min}$ once they reached their maximal growth rate [40]. Accordingly, they were able to obtain 2-fold increase in pectinase production. In our work, bioreactor cultivations were run at $1 \mathrm{v} / \mathrm{v} / \mathrm{min}$, in order to avoid increasing shear stress and consequently decreasing pectinase productivity. Furthermore, the decrease in growth and production rates in bioreactor cultivations can be explained due to the induction-repression or activation-inhibition mechanisms of pectinase production by $A$. niger [4, 41, 42]. The authors proposed that pectinase production is inhibited by catabolite repression through galacturonic acid units produced by the action of the enzyme on pectin, and that the galacturonic acid may be indirectly associated with the activation/inhibition mechanisms of pectinase production depending on its concentration in the medium.

Batch cultivation is generally terminated earlier due to exhaustion of important nutrient components from the cultivation medium, which greatly affects the overall productivity of the cultivation process. Therefore, fed-batch mode of cultivation was developed to overcome problems encountered in batch cultivations [36, 43]. Our obtained results showed a great improvement in pectinase production process upon feeding sucrose, where the volumetric production increased by about 4 folds. These results are in good accordance with those reported earlier 
in the literature concerning pectinase production. Tuttobello and Mill used pectin for the production of pectinase with $A$. niger [44]. They found that incorporating sucrose at a $4 \%$ concentration to the pectin medium greatly enhanced pectinase production, and that cells were able to utilize about $85 \%$ of the pectin contents in the medium. They also found that other carbohydrates tested did not show similar promoting effects. This can be supported with the work of Solís-Pereira et al. [4] who investigated the effects of different carbon sources on pectinase production by $A$. niger. They found that feeding sucrose to pectin containing medium greatly improved pectinase production due to its inductive effect. Moreover, Phutela et al. used wheat bran medium for the production of pectinase by A. fumigatus [45]. They found that supplementing their medium with sucrose resulted in about $37.8 \%$ increase in pectinase production than the control medium without sucrose addition.

\section{Conclusions}

In the present work, a new strain, Aspergillus niger NRC1ami, isolated from citrus fruit, showed high pectinase production using a statistically optimized medium. The medium variables affecting enzyme production were pectin, $\left(\mathrm{NH}_{4}\right)_{2} \mathrm{SO}_{4}$ and $\mathrm{K}_{2} \mathrm{HPO}_{4}$, while $\mathrm{MgSO}_{4}$ was found to be insignificant. The optimum medium composition statistically optimized (g/L) was: pectin, 32.22; $\left(\mathrm{NH}_{4}\right)_{2} \mathrm{SO}_{4}$, 4.33; $\mathrm{K}_{2} \mathrm{HPO}_{4}, 1.36 ; \mathrm{MgSO}_{4} .5 \mathrm{H}_{2} \mathrm{O}, 0.05 ; \mathrm{KCl}, 0.05$; and $\mathrm{FeSO}_{4} \cdot 5 \mathrm{H}_{2} \mathrm{O}, 0.10$. Medium optimization enhanced pectinase production by about 2.8 folds (from 27.2 to $76.35 \mathrm{U} /$ $\mathrm{mL}$ ). The enzyme yield was further improved by about 4-folds upon transferring the process from shake flasks to bioreactor under controlled $\mathrm{pH}$. Further improvement was achieved by fed-batch cultivation with constant carbon source feeding on a semi-industrial scale in $16-\mathrm{L}$ stirred tank bioreactor. Maximal volumetric enzyme production increased by about 16.5 -folds from the initial starting conditions. Finally, the high yield obtained in the semi-industrial scale bioreactor supports the scaling-up and industrialization of this process.

\section{Abbreviations}

ANOVA: Analysis of variance; BB: The Box-Behnken; CDW: Cell Dry Weight; PBED: Plackett-Burman Experimental Design

Acknowledgments

Not applicable.

\section{Funding}

This work was funded by UTM Research Management Centre, Universiti Teknologi Malaysia (Project: Q.J130000.2609.06 J04) and Deanship of Scientific Research, King Saud University (RGP-1435-047). Funding was obtained based on the proposed study and the funding bodies had no further role in data collection, analysis, interpretation or manuscript preparation.
Availability of data and materials

All the data generated in this current work are included in the 'Result and Discussion'.

\section{Authors' contributions \\ HAE and EAE proposed the research concept, designed the experiments, provided necessary tools for experiments, experimental instructions, analyzed and interpreted the data and wrote the manuscript. EAE, NS and RAM carried out the experimental work. ME provided the microbial strain and analyzed the data. All authors read and approved the final manuscript.}

Ethics approval and consent to participate

Not applicable.

\section{Consent for Publication}

Not applicable.

\section{Competing interests}

The authors declare that they have no competing interests.

\section{Publisher's Note}

Springer Nature remains neutral with regard to jurisdictional claims in published maps and institutional affiliations.

\section{Author details}

${ }^{1}$ Institute of Bioproduct Development (IBD), Universiti Teknologi Malaysia (UTM), 81130 UTM, Skudai, Malaysia. ${ }^{2}$ City of Scientific Research and Technology Application, New Burg Al Arab, Alexandria, Egypt. ${ }^{3}$ Bioproducts Research Chair, Zoology Department, Faculty of Science, King Saud University, 11451 Riyadh, Kingdom of Saudi Arabia. ${ }^{4}$ Chemistry of Natural and Microbial Products Department, National Research Centre, 12622 Dokki, Cairo, Egypt.

Received: 26 June 2018 Accepted: 24 October 2018 Published online: 09 November 2018

\section{References}

1. Saranraj P, Naidu MA. Microbial pectinases: a review. Global J Trad Med Syst. 2014:3(1):1-9.

2. Markets and Markets. Fruit \& Vegetable Processing Enzymes Market by Application (Fruits and Vegetables), Form (Liquid and Powder), Source (Bacteria and Fungi), Type (Amylase, Pectinase, Protease, and Cellulase), Product Type, and Region - Global Forecast to 2022. 2017. https://www. marketsandmarkets.com/Market-Reports/fruit-vegetable-processingenzymes-market-253649892.html.

3. Ruiz HA, Rodriguez-Jasso R, Rodríquez R, Contreras-Esquivel JC, Aguilar CN. Pectinase production from lemon peel pomace as support and carbon source in solid-state fermentation column-tray bioreactor. Biochem Eng J. 2012;65:90-5.

4. Solís-Pereira S, Favela-Torres E, Viniegra-González G, Gutiérrez-Rojas M. Effect of different carbon sources on the synthesis of pectinases by Aspergillus niger in submerged and solid state fermentations. Appl Microbiol Biotechnol. 1993:39(1):36-41.

5. Reddy M, Saritha KV. Effects of the culture media optimization on pectinase production by Enterobacter sp. PSTB-1. J Biotech. 2016;6(2):207.

6. Kashyap DR, Vohra PK, Chopra S, Tewari R. Application of pectinases in the commercial sector: a review. Bioresour Technol. 2001;77(3):215-27.

7. Sharma S, Mandhan RP, Sharma J. Utilization of agro-industrial residues for pectinase production by the novel strain Pseudomonas sp. SPJ under solid state cultivation. Ann Microbiol. 2012;62:169-76.

8. Jayani RS, Saxena S, Gupta SR. Microbial pectinolytic enzymes: a review. Process Biochem. 2005;40(9):2931-44.

9. Tepe O, Dursun AY. Exo-pectinase production by Bacillus pumilus using different agricultural wastes and optimizing of medium components using response surface methodology. Environ Sci Pollut Res. 2014;21:9911-20.

10. Ghazala I, Sayari N, Romdhane MB, Ellouz-Chaabouni S, Haddar A. Assessment of pectinase production by Bacillus mojavensis 14 using an economical substrate and its potential application in oil sesame extraction. J Food Sci Technol. 2015;52(12):7710-22. 
11. Martin N, de Souza SR, da Silva R, Gomes E. Pectinase production by fungal strains in solid-state fermentation using agro-industrial bioproduct. Braz Arch Biol Technol. 2004;47(5):813-9.

12. Favela-Torres E, Volke-Sepúlveda T, Viniegra-González V. Production of hydrolytic depolymerising pectinases. Food Technol Biotechnol. 2006:44(2):221-7.

13. Tari C, Gögus N, Tokatli F. Optimization of biomass, pallet size and polygalacturonase production by Aspergillus sojae ATCC 20235 using response surface methodology. Enzym Microb Technol. 2007:40(5):1108-16.

14. Teixeira JA, Gonçalves DB, de Queiroz MV, de Araújo EF. Improved pectinase production in Penicillium griseoroseum recombinant strains. J Appl Microbiol. 2011;111(4):818-25.

15. Benoit I, Coutinho PM, Schols HA, Gerlach JP, Henrissat B, de Vries RP. Degradation of different pectinase by fungi: correlations and contrasts between the pectinolytic enzyme sets identified in genomes and the growth on pectins of different origin. BMC Genomics. 2012;13(1):321.

16. Heerd D, Yegin S, Tari C, Fernandez-Lahore M. Pectinase enzyme-complex production by Aspergillus spp. in solid-state fermentation: a comparative study. Food Bioprod Process. 2012;90(2):102-10.

17. Kuvvet C, Uzuner S, Cekmecelioglu D. Improvement of pectinase production by co-culture of Bacillus spp. using apple pomace as a carbon source. Waste Biomass Valor. 2017. https://doi.org/10.1007/s12649-017-0142-4.

18. Iwashita K. Review: recent studies of protein secretion by filamentous fungi. J Biosci Bioeng. 1989;94(6):530-5.

19. Esawy MA, Gamal AA, Kamel Z, Ismail AS, Abdel-Fattah AF. Evaluation of free and immobilized Aspergillus niger NRC1ami pectinase applicable in industrial processes. Carbohyd Polym. 2013;92(2):1463-9.

20. Hibbert DB. Experimental design in chromatography: a tutorial review. J Chromatog B. 2012;910:2-13.

21. Abdel Fattah YR, El-Enshasy HA, Soliman NA, El Gendi H. Bioprocess development for the production of alkaline protease by Bacillus pseudoformus Mn6 through statistical experimental design. J Microbiol Biotechnol. 2009:19:378-86.

22. Then C, Wai OK, Elsayed EA, Mustapha WZW, Othman NZ, Aziz R, Wadaan M, El Enshsay HA. Comparison between classical and statistical medium optimization approaches for high cell mass production of Azotobacter vinelandii. J Sci Ind Res. 2016;75:231-8.

23. Soltani M, Abd Malek R, Ware I, Ramli S, Elsayed EA, Aziz R, El Enshasy HA. Optimization of cordycepin extraction from Cordyceps militaris fermentation broth. J Sci Ind Res. 2017;76:355-61.

24. Huong DM, Luyen DV. Optimization of pectin extraction from dried peel of Citrus grandis. Polym Bull. 1989;22:599-602.

25. Dinarvand $M$, Rezaee $M$, Masomian M, Jazayeri SD, Zareian M, Abbasi S, Ariff $A B$. Effect of $C / N$ ratio and media optimization through response surface methodology on simultaneous production of intra- and extracellular inulinase and invertase from Aspergillus niger ATCC 20611. Biomed Res Int. 2013;2013:1-13. Article ID 508968.

26. Debing J, Peijun L, Stagnitti F, Xianzhe X, Li L. Pectinase production by solid fermentation from Aspergillus niger by a new prescription experiment. Ecotoxicol Environ Safety. 2006:64(2):244-50.

27. Li P-J, Xia J-L, Shan Y, Nie Z-Y, Su D-L, Gao Q-R, Zhang C, Ma Y-L. Optimizing production of pectinase from orange peel by Penicillium oxalicum PJ02 using response surface methodology. Waste Biomass Valor. 2015;6:13-22.

28. Yu P, Xu C. Production optimization, purification and characterization of a heat-tolerant acidic pectinase from Bacillus sp. ZJ1407. Inter J Biol Macromol. 2018;108:972-80.

29. Çiftçi M, Özmen I, Büyükokuroǧlu EM, Pençe $S$, Küfrevioǧlu Öl. Effects of metamizol and magnesium sulfate on enzyme activity of glucose 6 phosphate dehydrogenase from human erythrocyte in vitro and rat erythrocyte in vivo. Clin Biochem. 2001;34:297-302.

30. Weurman C. Pectinase inhibitors in pears. Acta Botan Neerland. 1953;2:107-21.

31. Wennekes LMJ, Goosen T, van den Broek PJM, van den Broek HWJ. Purification and characterization of glucose-6-phosphate dehydrogenase from Aspergillus niger and Aspergillus nidulans. J Gen Microbiol. 1993;139:2793-800.

32. El Enshasy HA, Elsayed EA. Kinetics of cell growth and invertase production by the biotherapeutic yeast, Saccharomyces boulardii. J Sci Ind Res. 2017:76(8):477-84.
33. Sharma DC, Satyanarayana TA. A marked enhancement in the production of a highly alkaline and thermostable pectinase by Bacillus pumilus dcsr1 in submerged fermentation by using statistical methods. Bioresour Technol. 2006:97:727-33.

34. El Enshasy $\mathrm{H}$, Kleine J, Rinas U. Agitation effects on morphology and protein productive fractions of filamentous and pelleted growth forms of recombinant Aspergillus niger. Process Biochem. 2006;41(10):2103-12.

35. Dailin DJ, Elsayed EA, Othman NZ, Malek R, Phin HS, Aziz R, Wadaan M, El Enshasy HA. Bioprocess development for kefiran production by Lactobacillus kefiranofaciens in semi industrial scale bioreactor. Saudi J Biol Sci. 2016:23:495-502

36. Elsayed EA, Omar HG, Galil SA, El Enshasy HA. Optimization of fed-batch cultivation strategy for extracellular a-amylase production by Bacillus amyloliquefaciens in submerged culture. J Sci Ind Res. 2016;75:480-6.

37. Vitolo M, Duranti MA, Pellegrim MB. Effect of $\mathrm{pH}$, aeration and sucrose feeding on invertase activity of intact Saccharomyces cerevisiae cells grown in sugarcane black strap molasses. J Ind Microbiol Biotechnol. 1995;15:75-9.

38. Naidu GSN, Panda T. Production of pectolytic enzymes - a review. Bioprocess Eng. 1998;19:335-61.

39. Rinas U, El Enshasy H, Emmler M, Hille A, Hempel DC, Horn H. Model-based prediction of substrate conversion and protein synthesis and excretion in recombinant Aspergillus niger biopellets. Chem Eng Sci. 2005;60(10):2729-39.

40. Friedrich J, Cimerman A, Steiner W. Submerged production of pectolytic enzymes by Aspergillus niger: effect of different aeration/agitation regimes. Appl Microb Technol. 1989;31:490-4.

41. Aguilar G, Huitrón C. Stimulation of the production ofextracellular pectinolytic activities of Aspergillus sp. by galacturonic acid and glucose addition. Enzym Microb Technol. 1987;9:690-6.

42. Aguilar G, Huitrón C. Constitutive exo-pectinase produced by Aspergillus sp. CH-Y-1043 on different carbon source. Biotechnol. 1990;12(9):655-61.

43. Sphor A, Carlsen M, Nielsen J, Villadsen J. a-Amylase production in recombinant Aspergillus oryzae during fed-batch and continuous cultivations. J Fermen Bioeng. 1998:86(1):49-56.

44. Tuttobello R, Mill PJ. The pectic enzymes of Asspergillus niger. Biochem J. 1961:79:51-6.

45. Phutela U, Dhuna V, Sandhu S, Chadha BS. Pectinase and polygalacturonase production by thermophilic Aspergillus fumigatus isolated from decomposting orange peels. Braz J Microbiol. 2005;36:63-9.

\section{Ready to submit your research? Choose BMC and benefit from:}

- fast, convenient online submission

- thorough peer review by experienced researchers in your field

- rapid publication on acceptance

- support for research data, including large and complex data types

- gold Open Access which fosters wider collaboration and increased citations

- maximum visibility for your research: over $100 \mathrm{M}$ website views per year

At BMC, research is always in progress.

Learn more biomedcentral.com/submissions 